\title{
Effect of a marine reserve on the distribution of coral reef fishes in Barbados
}

\author{
Ana Rakitin ${ }^{1,2, *}$, Donald L. Kramer ${ }^{1}$ \\ 'Department of Biology, McGill University, 1205 Avenue Docteur Penfield, Montreal, Quebec, Canada H3A 1B1 \\ ${ }^{2}$ Bellairs Research Institute of McGill University, Holetown, St. James, Barbados
}

\begin{abstract}
High population densities of larger fish within reserves could result in emigration of fish to surrounding non-reserve areas, producing a gradient of abundance and mean size across the reserve boundaries. The difference in fish abundance and size between reserve and non-reserve should be higher for sedentary than for mobile species and for highly catchable than for less catchable species. To test these hypotheses we estimated the abundance and size of fishes by trapping and visual census on fringing reefs in Barbados: 5 reefs within the $2.2 \mathrm{~km}$ of the Barbados Marine Reserve (BMR) and 8 reefs in the non-reserve (NR) area within $4 \mathrm{~km}$ of the reserve boundaries. The abundance of large, trappable size fish of all species combined was higher in the BMR than in the NR, but abundance of small, nontrappable fish did not differ between BMR and NR. Trap catches decreased gradually with distance from the BMR center, but this gradient of abundance was less evident in visual census counts of trappable size fishes of all species combined, and not apparent in trap or visual census estimates of abundance for individual species. Mean size was larger in the BMR than in the NR for 18 out of 24 species. The relative differences in both abundance and size between BMR and NR did not differ between mobile and sedentary fish taxa. However, for sedentary taxa, the relative differences in abundance and size increased with trappability (the vulnerability to traps, which are the most common fishing method). These patterns suggest that the BMR does protect the fish community from fishing mortality and that emigration rates are generally low. Trappability and mobility depend on complex behavioral characteristics of fishes and are potentially important for the functioning of marine reserves.
\end{abstract}

KEY WORDS: Marine reserve - Tropical fisheries . Fish traps - Visual census - Fish movements . Barbados · Caribbean · Coral reefs

\section{INTRODUCTION}

Over the past 40 yr marine reserves have been established at numerous locations throughout the world in the interest of conservation, recreation, education and resource management (Wallis 1971, Pollard 1977. Upton 1992). The role of reserves in the management of coral reef fisheries has gained interest in recent years (Roberts \& Polunin 1991, 1993, DeMartini 1993). Marine reserves have the potential to maintain and/or enhance surrounding fisheries. They may restore fish stocks, particularly spawning stocks, within their boundaries and act as sources of larvae

\footnotetext{
- Present address: Department of Zoology. University of Guelph, Guelph, Ontario, Canada N1G2W1.

E-mail:arakitin@uoguelph.ca
}

that could eventually settle outside of the reserve. Reserves could also enhance fisheries by supplying postsettlement juveniles or adults as emigrants (Roberts \& Polunin 1991, DeMartini 1993). The effectiveness of these 2 functions depends on the degree of movement of fishes across the reserve boundaries, but in opposite ways: to protect a spawning stock emigration should be low, but to supply postsettlement recruits there must be significant emigration.

If fish population density is higher inside a reserve than in adjacent non-reserve (fishery) areas, random movements will produce a net emigration from the reserve. Furthermore, frequency-dependent models of animal distribution such as the Ideal Free Distribution (Fretwell \& Lucas 1970) predict that animals should prefer to move from areas where their density is high relative to resources to areas where it is lower, if their 

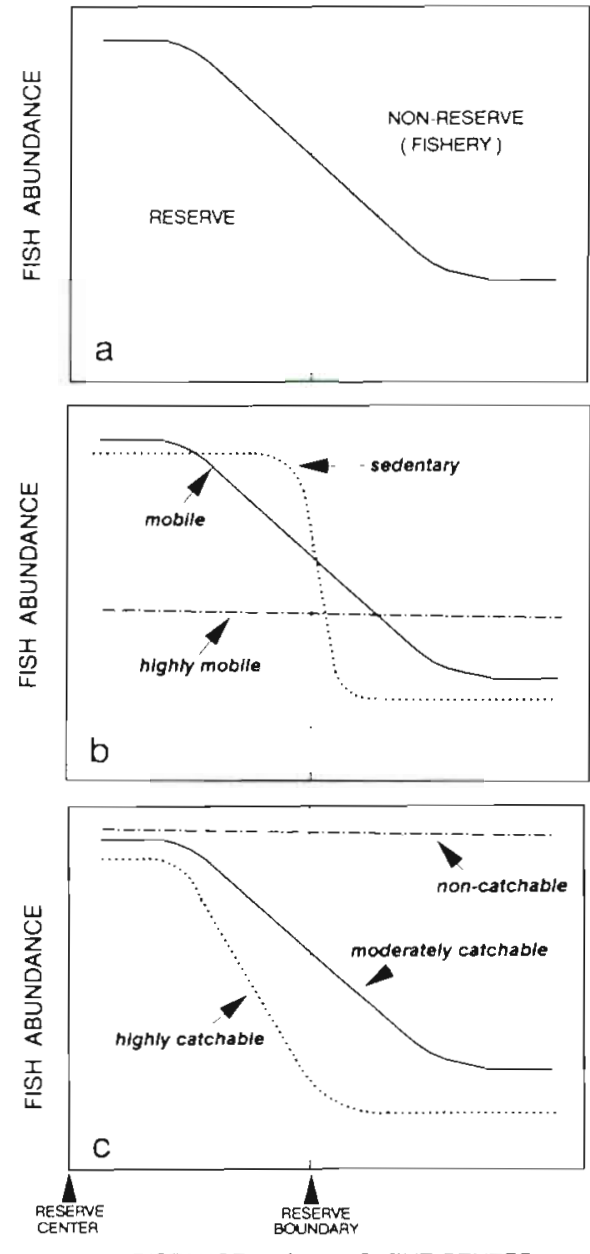

DISTANCE FROM RESERVE CENTER

Fig. 1. Hypothetical effect of marne reserves on the distribution of fishes: (a) when all taxa have equal catchability and mobility; (b) when fish taxa differ in their mobility but have equal catchability; (c) when fish taxa differ in catchability but not in mobility

fitness is affected by the interaction between population density and resource availability (e.g. Power 1984).

Coral reef fish are generally described as sedentary once they settle on a reef after a pelagic larval stage (Sale 1980). However, many species undertake relatively extensive migrations that can range from a few meters up to several kilometers (Hobson 1973). These migrations could take fish out of the reserve.

If emigration from reserves is an important factor determining the distribution of fishes, their abundance should be maximal in the center of the reserve decreasing gradually toward and beyond the boundaries (Fig. 1a). Fish with home ranges centered in the reserve but close to the boundary are more likely to be sometimes outside and, hence, more likely to relocate to non-reserve sites than fish in the center of the reserve. Relocating fishes should initially occupy sites outside the reserve but near the boundary. The frequency of relocating fishes should decrease farther from the reserve boundary due to their low mobility and to fishing mortality. However, highly mobile fish could easily relocate from areas close to the center of a reserve to areas far outside the reserve. Hence, mobile fish should exhibit a shallower gradient of abundance across the reserve boundaries than sedentary fish (Fig 1b). Additionally, fish that are not vulnerable to fishing (noncatchable) due to a small size or to behavioral traits, such as avoiding or escaping from the fishing gear, should not be directly affected by the reserve (although indirect effects, such as through trophic or competitive relationships, are possible). Noncatchable fish should show an even distribution across the reserve boundary. As catchability increases, population sizes outside the reserve should be depressed to a greater extent. Hence, gradients of abundance between the reserve and the fishery areas should be steeper for highly catchable than for moderately catchable fish (Fig. 1c). This suggests that reserves will function differently in terms of protecting or supplying fishes to nearby areas according to behavioral traits of the species involved: fish with high catchability and low mobility should be the most affected by the reserve (see also DeMartini 1993). Reserves should affect mean size of fish in a similar way they affect abundance. Mean size should be smaller in non-reserve than in reserve areas because fishing mortality will reduce the proportion of older (hence larger) fish in the non-reserve.

Previous studies provided evidence strongly suggesting that marine reserves enhance the abundance and size of certain fish species (usually fishery target species) within their boundaries (Bohnsack 1982, Bell 1983, Alcala 1988, Buxton \& Smale 1989, Russ \& Alcala 1989, Roberts \& Polunin 1991, Bohnsack et al. 1992, Polunin \& Roberts 1993). However, there is little information concerning movement of fishes out of reserves or other biological correlates of differences among species in the protective effect of reserves.

In this study we analyzed the distribution of coral reef fishes in shallow water (less than $10 \mathrm{~m}$ ) in a marine reserve in Barbados and in the adjacent fishery area in an attempt to answer 2 questions: (1) does the reserve effectively protect fish stocks within its boundaries and (2) is there emigration of fish from the reserve? To answer these questions we defined 3 specific objectives. The first was to determine whether fish were more abundant and of larger size in the Barbados Marine Reserve than in the adjacent nonreserve area. The second objective was to examine the pattern of fish abundance in relation to distance from the reserve center. The third objective was to 
assess whether differences among taxa in mobility and catchability were related to relative differences in abundance and size between reserve and non-reserve areas. Specifically, we tested the hypotheses that mobile taxa were less affected by the reserve than sedentary taxa and that taxa highly susceptible to the fishery were more affected by the reserve than taxa with low catchability.

\section{METHODS}

Study area. The study was conducted on an $8 \mathrm{~km}$ shoreline section of the west (leeward) coast of Barba$\operatorname{dos}\left(59^{\circ} 38^{\prime} \mathrm{W}, 13^{\circ} 09^{\prime}\right.$ to $13^{\circ} 12^{\prime} \mathrm{N}$; Fig 2). Fringing reefs are found only on the west coast of the island growing as flame-shape structures on a gently sloping shelf extending about $300 \mathrm{~m}$ from the beach to a depth of $10 \mathrm{~m}$ (Lewis 1960, Stearn et al. 1977). Reefs are not continuous along the shore but are separated by 50 to $800 \mathrm{~m}$ wide areas of sand and rubble with occasional small (less than $2 \mathrm{~m}$ in diameter) patch reefs. In this study reefs were divided into 3 ecological zones based on Lewis (1960) and Stearn et al. (1977). The backreef

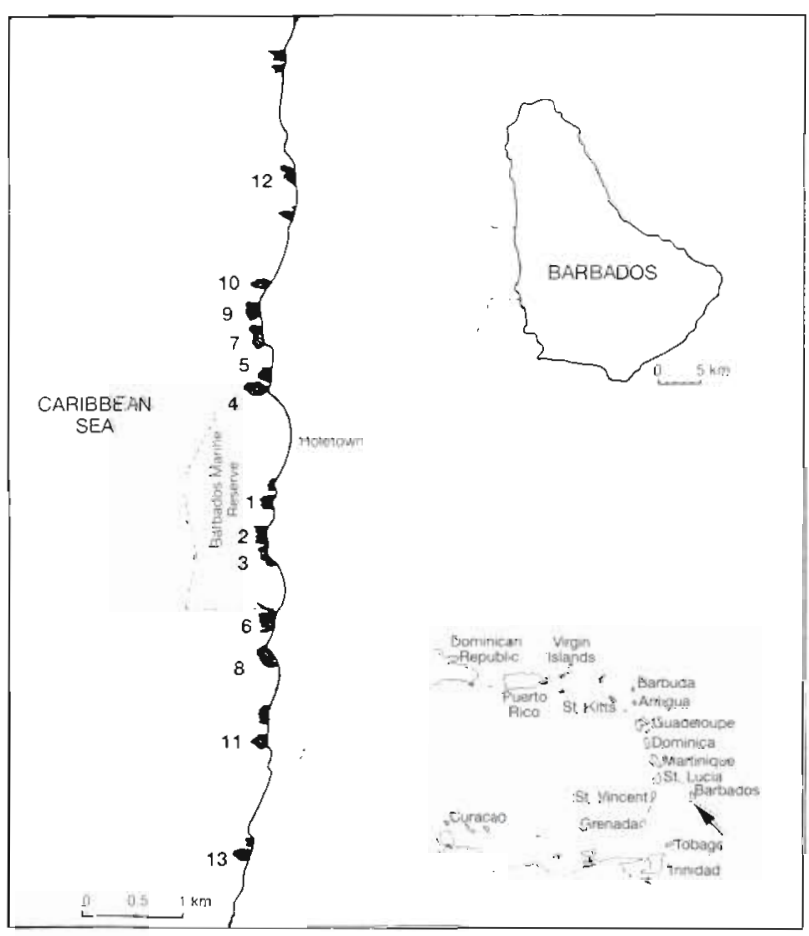

Fig. 2. Map of the study area. Lower right: the Caribbean region; arrow indicates Barbados. Upper nght: Barbados island; dashed lines show the location of the study area. Left the study ared on the west coast of Barbados showing the location of the Barbados Marine Reserve (dashed lines) and the fringing reefs (shaded). Reefs are numbered according to increasing distance from the center of the Reserve was the zone adjacent to the shore, 0 to $1 \mathrm{~m}$ depth at low tide, formed by nearly flat and mostly dead coral rock covered by sand and filamentous algae. The reef crest was the zone extending approximately $50 \mathrm{~m}$ seaward of the backreef, 1 to $2.5 \mathrm{~m}$ depth, formed by mostly dead reef with some live coral heads and characterized by high rugosity. The spurs-and-grooves zone was at the seaward edge of the reef with the tops of the reef spurs 2 to $3 \mathrm{~m}$ deep and the sand bottomed grooves 4 to $8 \mathrm{~m}$ deep.

The study area comprised a marine reserve area and a non-reserve area. The first was the inshore area along the entire $2.2 \mathrm{~km}$ length (north-south) of the Barbados Marine Reserve (BMR), including 5 fringing reefs. The BMR was officially established in 1981 and is managed by the National Conservation Commission of the Ministry of Tourism and the Environment. Fishing is banned in the BMR, with the exception of cast netting for clupeids (St. Hill 1987, Wells 1988). However, the enforcement of the reserve management regulations is not strong enough to prevent a certain amount of illegal fishing (especially spearfishing).

The non-reserve (NR) was part of an area open to the fishery adjacent to the reserve, stretching approximately $3.5 \mathrm{~km}$ to the north and $3.5 \mathrm{~km}$ to the south of the reserve boundaries and comprising 8 fringing reefs: 4 north and 4 south of the BMR (Fig. 2). Antillean fish traps are the most common fishing method in Barbados (Miller \& Hunte 1987) as in other areas of the Caribbean (Munro 1974, 1983). Trap fishing goes on year-round; however, the fishing effort is much higher between June and December when there is no fishing for pelagic species, and is lower during the peak of the pelagic fishing season between January and May. There are no data available on the amount of trap fishing outside of the BMR. Interviews with fishermen suggest that 40 to 60 traps are set and hauled twice a week within each of the non-reserve areas (north and south of the BMR) surveyed in this study.

Fish survey. Fish surveys on reefs were conducted between August and December 1992 using fish traps and visual censuses.

Trapping: Traps sample nocturnal as well as diurnal species and permit nondestructive measurement and identification of specimens (Miller \& Hunte 1987), but their selectivity depends on complex and poorly understood behavioral traits of fishes (Munro 1974). Arrowhead-shaped traps with 1 entrance funnel (approximate size $1.8 \times 1.5 \times 0.6 \mathrm{~m}$ ) were used, because they are the most common design in Barbados (Miller \& Hunte 1987). They consist of a frame of wooden poles covered by galvanized chicken wire, $3.5 \times 4.5 \mathrm{~cm}$ hexagonal mesh. Traps were not baited since most commercial fishermen do not bait their traps. They were placed on sandy bottom within $2 \mathrm{~m}$ of the sea- 
ward edge of the reef near the corresponding visual census area and left for $4 \mathrm{~d}$ before hauling. All the fishes captured were identified, measured [fork length $(F L)$ to the nearest $0.5 \mathrm{~cm}$ and maximum body height to the nearest $1 \mathrm{~mm}$ and immediately released at the place of capture. There were 42 successful trap sets: 19 in the BMR and 23 in the NR ( 2 to 5 trap sets per reef) The sequence of sampling and the number of successful trap sets per reef were affected by weather conditions and loss of traps (possibly due to accidental dragging by speed boats). No successful trap sets were achieved on Reef 13 (Fig. 2). Only 1 trap was set on a reef at a time, and no visual census was performed on a reef while a trap was there.

Visual census: Each visual census covered a $240 \mathrm{~m}^{2}$ area of the reef. On the 8 larger reefs (Reefs $2,4,5,6$, $7,9,11 \& 12 ;$ Fig. 2) 1 census area was laid out in each reef zone: the backreef, the reef crest and the spursand-grooves zone. On the 5 smaller reefs (Reets $1,3,8$, $10 \& 13$; Fig. 2) only 2 census areas could be laid out: in the backreef and in the spurs-and-grooves zone. However, because reef crest did not differ statistically from reef spurs-and-grooves in either habitat structural complexity (Rakitin 1994) or fish abundance (see 'Results') these 2 reef zones were combined in a crestspurs zone to simplify the analysis of data. Fish abundance in the combined crest-spurs zone was estimated as follows: for the 8 larger reefs the average abundance between reef crest and spurs-and-grooves zones was taken and for the 5 smaller reefs fish abundance in the spurs-and-grooves was used directly. Backreef was considered separately. To facilitate counting, the census area was divided into 3 strips (transects) $4 \mathrm{~m}$ wide and $20 \mathrm{~m}$ long, demarcated by four $20 \mathrm{~m}$ ropes laid out on the reef parallel to each other and perpendicular to the shoreline. The census was carried out by a diver swimming along each transect, counting and recording all the fishes by taxon and size class (FL $<5,5-10,10-15,15-20,20-25,25-30$ and $>30 \mathrm{~cm}$ ). Two counts were made on each transect. During the first count individuals of $\mathrm{FL}>10 \mathrm{~cm}$ were counted over the total transect area $(4 \times 20 \mathrm{~m})$. During the second count the more numerous and more easily overlooked fish of $\mathrm{FL}<10 \mathrm{~cm}$ were counted on a $1 \times$ $20 \mathrm{~m}$ section of the same transect. Thus fish of FL > $10 \mathrm{~cm}$ were counted over $240 \mathrm{~m}^{2}$ and fish with $\mathrm{FL}<$ $10 \mathrm{~cm}$ over $60 \mathrm{~m}^{2}$. The time to census a $240 \mathrm{~m}^{2}$ area was approximately $30 \mathrm{~min}$ in the backreef and $45 \mathrm{~min}$ in each of the other zones. Censuses were conducted between 09:00 and 17:00 h and only when visibility was at least $5 \mathrm{~m}$. Each reef was censused 3 times (same census areas) at intervals of approximately 1 mo during the 4 mo of this study.

All the visual censuses were performed by the same observer (A.R.). Prior to data collection, the observer trained for underwater size estimation by estimating the size of fish inside a trap under water and checking the estimations after hauling the trap. Training was stopped when the error of estimation was less than $10 \%$ of FL. Because of difficulties in distinguishing some species, several related species were sometimes combined into a single collective taxon.

Minimum trappable size: Fishes counted in the visual censuses were divided into trappable or nontrappable according to their size. Fishes were considered trappable if they were large enough to be retained by the $4.5 \times 3.5 \mathrm{~cm}$ commercial trap mesh. Because fishermen usually use the entire catch for sale, personal consumption or bait, all trappable size fish are potentially vulnerable to the fishery. A minimum trappable FL was defined as the FL corresponding to a body height of $4.5 \mathrm{~cm}$ and estimated by linear regressions of FL on body height, for all species with a sufficient range of sizes (Rakitin 1994). In the visual census fish size was estimated with a precision of $5 \mathrm{~cm}$, so the estimated minimum trappable FL was rounded to the nearest $5 \mathrm{~cm}$. Minimum trappable FL was estimated from fish with similar body shape for species that were present in the visual censuses but not in traps or that were uncommon in traps. Because fish with $\mathrm{FL}>10 \mathrm{~cm}$ were censused over $240 \mathrm{~m}^{2}$, for taxa with a minimum trappable size of $15 \mathrm{~cm}$ the abundance of nontrappable fishes was corrected to mean number of fish per $60 \mathrm{~m}^{2}$ by adding the mean number of fish with $\mathrm{FL}<10 \mathrm{~cm}$ in the $60 \mathrm{~m}^{2}$ census area plus 0.25 times the mean number of fish in the size class FL 10 to $15 \mathrm{~cm}$ in the $240 \mathrm{~m}^{2}$ census area.

Trappability. The trappability, i.e. the catchability or vulnerability of a given fish taxon to traps, was estimated as the ratio of the mean number of fish of that taxon per trap, averaged over all reefs, to the mean number of trappable size fish of the same taxon per census area in the combined crest-spurs zone, averaged over all reefs.

Mobility. Fish taxa were classified as either mobile (M) or sedentary (S) based on literature reports, supplemented by trapping in the sand and rubble gaps between the surveyed reefs. In the literature we looked for evidence of migration off the reef or specific definition of home range size and movement patterns. Every species that was reported to feed or travel over open sand was classified as $M$ because it was considered capable of moving from one reef to another. Species reported to exclusively use reef areas to feed, rest and spawn were classified as $\mathrm{S}$. To estimate the local movement habits of reef fish in Barbados between October and December 1993, a year after completing the main sampling, traps were set on the sand and rubble areas separating reefs, at various distances from the reefs (approximately 50,150 and $300 \mathrm{~m}$ ) following 
the same procedure as during the trapping on reefs. The traps were set in the 4 large sand and rubble gaps between Reefs 5 and 7,1 and 4,1 and 2,3 and 6 (Fig. 2). A total of 28 trap sets were successful. Taxa that had been classified as $\mathrm{S}$ or unknown based on the literature were called $\mathrm{S}$ if they did not appear in traps set on sand or if they appeared only in traps set $50 \mathrm{~m}$ from a reef, but were classified as $M$ if present in traps set 150 or $300 \mathrm{~m}$ from a reef. Taxa classified as $M$ based on the literature were still considered $M$ even if not captured in traps away from reefs.

Relative differences in abundance and size. Because the abundance and the mean size of fish differed largely among taxa, a direct difference of means between BMR and NR would not accurately represent the magnitude of the reserve effect on fish populations. In order to compare the effect of the reserve among taxa, the differences in abundance and size were standardized. The relative difference in fish abundance was defined as $\left(N_{\mathrm{BMR}}-N_{\mathrm{NR}}\right) / N_{\mathrm{BMR}}$, where $N_{\mathrm{BMR}}$ and $N_{\mathrm{NR}}$ are the mean abundances of trappable fish averaged over all sampled reefs in the BMR and in the NR, respectively. For trap data, $N_{B M R}$ and $N_{N R}$ were the mean numbers of fish per trap, and for visual census data, $N_{\mathrm{BMR}}$ and $N_{\mathrm{NR}}$ were the mean numbers of trappable fish per census area in the combined crest-spurs zone. Mean size differences were standardized to the maximum size of each species provided by Robins et al. (1986). Mean relative size difference was defined as $\left(F L_{B M R}-F_{L}\right) / F L_{\text {max }}$, where $F L_{B M R}$ and FLNR are the mean FL in the BMR and in the NR, respectively, estimated by trapping, and $\mathrm{FL}_{\max }$ is the maximum $\mathrm{FL}$ attained by the species.

Data analysis. For the analysis of fish abundance each reef was the sampling unit (replicate). For trapping, the mean number of fish per trap per reef was calculated averaging the number of fish captured in all the trap sets on each reef. For the visual censuses the mean number of fish per census area was calculated as the sum of fish counted on the 3 transects averaged over the 3 censuses. The census area was $240 \mathrm{~m}^{2}$ for trappable fish and $60 \mathrm{~m}^{2}$ for nontrappable fish. For the analysis of fish size each individual was a replicate. Normality of data was tested using Lilliefors probability. Abundance means and size means in the BMR and in the NR were compared by t-test and Mann-Whitney $U$-test. A chi-squared goodness of fit test (Zar 1984) was used to test whether the proportion of taxa showing a larger mean size and/or a larger mean abundance in the BMR than in the NR differed from the $50 \%$ expected by chance. The abundances of fish in the 3 reef zones were compared by ANOVA followed by Tukey test. Linear regression analysis was used to study the effect of distance from the BMR center on mean abundance. Relative differences in mean abun- dance and mean size were compared between $M$ and $S$ taxa by $t$-test and Mann-Whitney $U$-test. The effect of trappability on the relative differences in abundance and size was evaluated using linear regression (trappabilities were $\log _{10}$ transformed). The correlation between relative difference in abundance and relative difference in size for all the taxa was evaluated by a Spearman rank correlation test. The SYSTAT statistical package (Wilkinson 1990) was used for the statistical analysis of data.

\section{RESULTS}

\section{Species observed}

A total of 89 species belonging to 36 families were recorded in the study. The combining of species that could not be consistently identified resulted in a total of 69 taxa (Table 1). In the BMR 66 taxa were found and in the NR 62, of which 59 were common to both BMR and $\mathrm{NR}, 7$ were exclusive to the BMR and 3 exclusive to the NR. A total of 33 taxa were seen only in visual censuses and not in traps; 36 taxa were found in traps of which 2 were not seen in visual censuses (Table 1).

\section{Abundance in traps}

When all species were pooled together, fish catches in traps were significantly higher in the BMR than in the NR (Table 2). The mean number of fish per trap decreased with increasing distance from the reserve center (Fig. 3). A multiple regression analysis of mean number of fish per trap on distance from the BMR center and location of the reef (inside or outside the BMR) revealed a highly significant effect of distance (partial $p$ $=0.005, \mathrm{df}=10$ ) and no effect of reserve (partial $\mathrm{p}=$ $0.895, \mathrm{df}=1$; overall $r^{2}=0.76$ ). Although catches tended to be larger in reefs located south of the BMR center (mean $=32.9$ fish per trap, $\mathrm{SD}=9.4)$ than in reefs north of the BMR center (mean $=23.8, \mathrm{SD}=6.6$ ), this difference was not significant $(t=1.782$, $d f=8.9, p=0.109$ ).

For 25 of the 36 taxa found in traps the mean number of fish per trap was higher in the BMR than in the NR. This difference was statistically significant for only 2 taxa (Table 3), but the number of taxa with higher abundance in the BMR was significantly more than the $50 \%$ expected by chance $\left(\chi^{2}=5.4\right.$, df $=1, p<$ $0.025)$. For the 15 most common taxa, catches in the NR ranged from $19 \%$ (for Chaetodon striatus) to $163 \%$ (for Caranx ruber) of catches in the BMR (Table $3)$. When multiple regressions were calculated on the 6 most common taxa, none of them revealed a significant effect of distance, and only $C$. striatus showed a 
Table 1. List of scientific and common names of all taxa recorded in the study, grouped by family and presented in phylogenetic order after Nelson (1994). Minimum trappable FL: estimated FL corresponding to a body depth of $4.5 \mathrm{~cm}$ (rounded to the nearest $5 \mathrm{~cm}$ ). Visual census: total number of trappable size fishes (T) and all size fishes, trappable and nontrappable (T+NT). counted during the 3 visual censuses at the 13 reefs; trapping: total number of fish captured in the 42 trap sets at the 12 reefs surveyed by trapping in 1992

\begin{tabular}{|c|c|c|c|c|}
\hline \multirow[t]{2}{*}{ Taxon } & \multirow{2}{*}{$\begin{array}{l}\text { Minimum } \\
\text { trappable } \\
\text { FL }(\mathrm{cm})\end{array}$} & \multicolumn{2}{|c|}{ Visual census } & \multirow[t]{2}{*}{ Trapping } \\
\hline & & $\mathrm{T}$ & $\mathrm{T}+\mathrm{NT}$ & \\
\hline \multicolumn{5}{|l|}{ Dasyatidae } \\
\hline Dasyatis americana southern stingray & & 1 & 1 & 1 \\
\hline \multicolumn{5}{|l|}{ Muraenidae } \\
\hline Gymnothorax funebris green moray & & 0 & 0 & 1 \\
\hline G. moringa spotted moray & & 13 & 13 & 23 \\
\hline Muraena miliaris goldentail moray & & 18 & 18 & 0 \\
\hline \multicolumn{5}{|l|}{ Ophichthidae } \\
\hline Myrichthys oculatus goldspotted eel & & 20 & 20 & 0 \\
\hline \multicolumn{5}{|l|}{ Clupeidae } \\
\hline Harengula humeralis redear sardine & 15 & 2 & 27660 & 0 \\
\hline \multicolumn{5}{|l|}{ Synodontidae } \\
\hline Synodus spp. lizardfishes ${ }^{d}$ & 15 & 29 & 43 & 0 \\
\hline \multicolumn{5}{|l|}{ Mugilidae } \\
\hline Mugil curema white mullet & 15 & 177 & 177 & 47 \\
\hline \multicolumn{5}{|l|}{ Holocentridae } \\
\hline Holocentrus spp. squirrelfishes ${ }^{b}$ & 15 & 26 & 1248 & 35 \\
\hline Myripristis jacobus blackbar soldierfish & 15 & 37 & 307 & 3 \\
\hline \multicolumn{5}{|l|}{ Aulostomidae } \\
\hline Aulostomus maculatus trumpetfish & 50 & 131 & 152 & 0 \\
\hline \multicolumn{5}{|l|}{ Scorpaenidae } \\
\hline Scorpaena plumieri spotted scorpionfish & 15 & 16 & 18 & 11 \\
\hline \multicolumn{5}{|l|}{ Serranidae } \\
\hline Epinephelus fulvus coney & 15 & 76 & 82 & 0 \\
\hline Epinephelus spp. other groupers ${ }^{c}$ & 15 & 14 & 16 & 0 \\
\hline Hypoplectrus sp. hamlet & 10 & 0 & 3 & 0 \\
\hline Serranus tabacarius tobaccofish & 15 & 0 & 1 & 6 \\
\hline Rypticus saponaceus greater soapfish & 15 & 53 & 161 & 0 \\
\hline R. subbifrenatus spotted soapfish & 15 & 2 & 2 & 0 \\
\hline \multicolumn{5}{|l|}{ Grammatidae } \\
\hline Gramma loreto fairy basslet & 10 & 0 & 9 & 0 \\
\hline \multicolumn{5}{|l|}{ Priacanthidae } \\
\hline Priacanthus spp. bigeyes ${ }^{d}$ & 15 & 46 & 46 & 0 \\
\hline Apogon spp cardinalfishes ${ }^{e}$ & 15 & 0 & 24 & 3 \\
\hline \multicolumn{5}{|l|}{ Carangidae } \\
\hline Caranx crysos blue runner & 15 & 99 & 101 & 1 \\
\hline C. latus horseye jack & 15 & 29 & 29 & 24 \\
\hline C. ruber bar jack & 15 & 130 & 135 & 4 \\
\hline \multicolumn{5}{|l|}{ Lutjanidae } \\
\hline Lutjanus mahogoni mahogany snapper & 15 & 48 & 104 & 3 \\
\hline Ocyurus chrysurus yellowtail snapper & 15 & 1 & 2 & 0 \\
\hline Gerreidae & & & & \\
\hline Gerres cinereus yellowfin mojarra & 15 & 3 & 3 & 0 \\
\hline Eucinostomus sp. mojarra & 15 & 15 & 67 & 26 \\
\hline Haemulidae & & & & \\
\hline Haemulon aurolineatum tomtate & 15 & 187 & 297 & 22 \\
\hline H. chrysargyreum smallmouth grunt & 15 & 711 & 1324 & 103 \\
\hline H. flavolineatum French grunt & 15 & 272 & 866 & 2 \\
\hline H. sciurus bluestriped grunt & 15 & 18 & 94 & 0 \\
\hline Sciaenidae & & & & \\
\hline Equetus spp.drums ${ }^{1}$ & 15 & 0 & 5 & 0 \\
\hline Odontoscion dentex reef croaker & 15 & 1 & 1 & 2 \\
\hline Mullidae & & & & \\
\hline Mulloidich thys martinicus yellow goatfish & 15 & 308 & 546 & 11 \\
\hline Pseudopeneus maculatus spolted goatfish & 15 & 40 & 43 & 0 \\
\hline Pempheridae & & & & \\
\hline Pempheris schomburgki glassy sweeper & 15 & 0 & $42 \gamma$ & 179 \\
\hline
\end{tabular}


Table 1 (contmued)

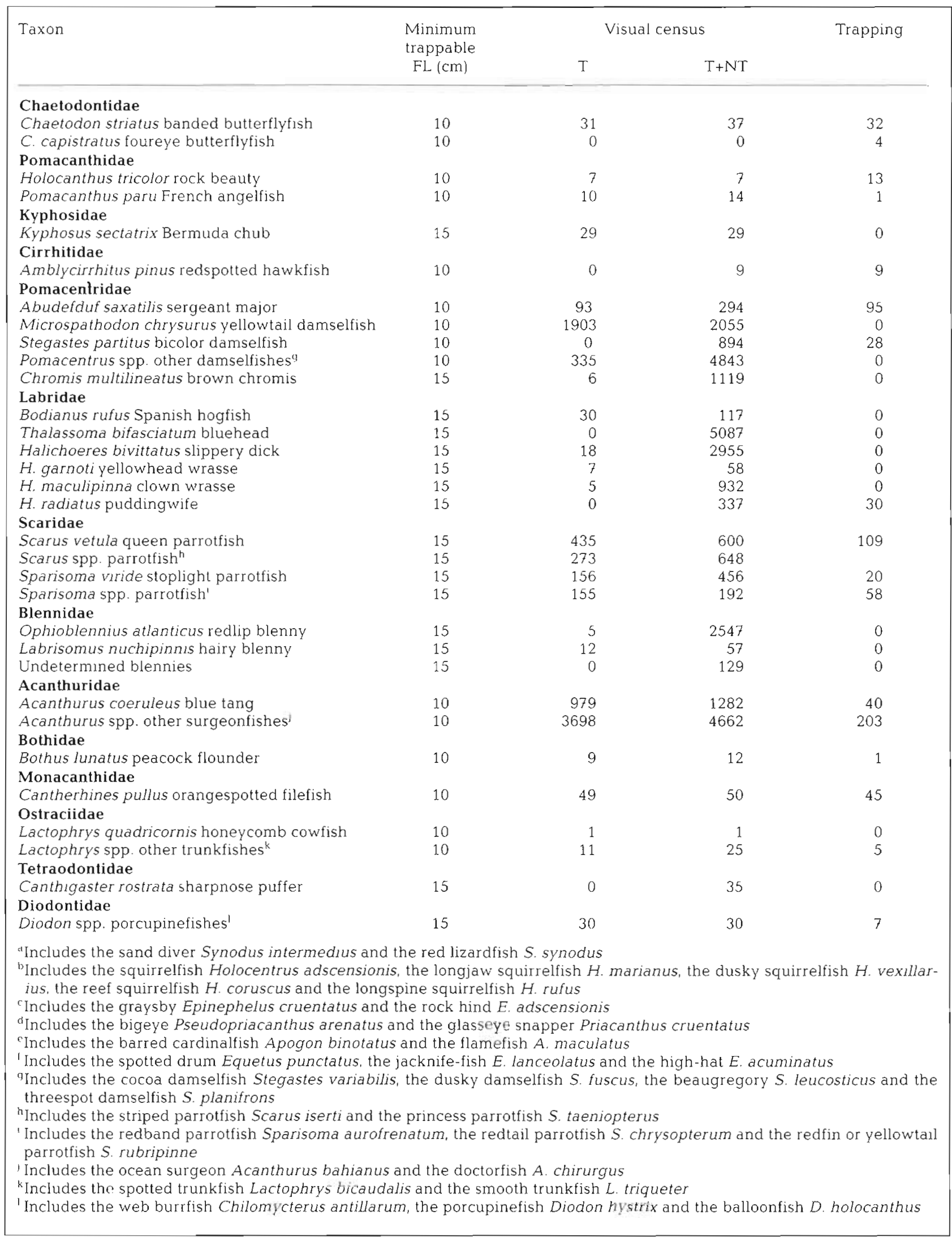




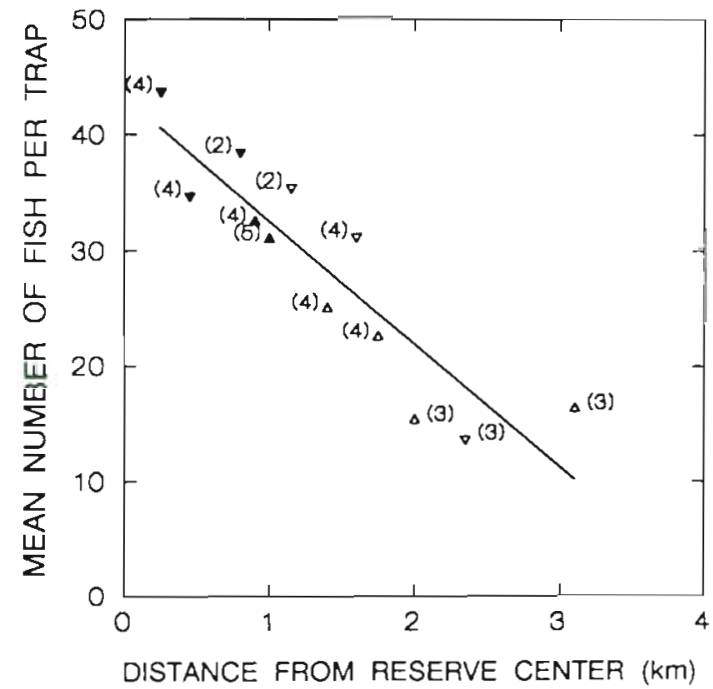

Fig. 3. Mean trap catches per reef of all species combined in relation to distance from the BMR center. Each point is the number of fish per trap averaged over all the trap sets on a reef (number of trap sets in parentheses). $(\boldsymbol{\Lambda}, \nabla)$ Reefs in the $\mathrm{BMR}_{i}(\Delta, \nabla)$ reefs in the NR; $(\nabla, \nabla)$ reefs south of the BMR center; $(\Delta, \Delta)$ reefs north of the BMR center; line: least squares linear regression

significant effect of reserve (partial $p=0.03, \mathrm{df}=1$; Fig. 4).

\section{Abundance in visual census}

Estimated minimum trappable FLs for each taxon are given in Table 1 . The mean number of nontrappable fish (all taxa combined) differed among reef zones ( $F=$ 9.61, $\mathrm{df}=2,31, \mathrm{p}=0.001$ ) and fishes were significantly less abundant in the backreef than in the reef crest ( $p=$ $0.004)$ and spurs-and-grooves $(p=0.001)$ but crest and spurs-and-grooves did not differ significantly $(\mathrm{p}=$ 0.686). For trappable fish (all taxa combined), abundance did not differ significantly among the 3 reef zones $(F=1.51, \mathrm{df}=2,31, \mathrm{p}=0.238)$, although means still tended to be higher in crest and spurs-andgrooves than in backreef. Because no difference was found between reef crest and spurs-and-grooves in overall fish abundance, only 2 reef zones, the backreef and the combined crest-spurs, were considered for further data analyses.

The abundance of trappable fish (all taxa combined) was significantly higher in the BMR than in the NR in each of the 2 reef zones (Table 2). For nontrappable fish there was no significant difference between BMR and NR, although means in NR were slightly higher (Table 2)

Contrary to the results of trapping data, in the visual censuses the abundance of trappable fish did not show
Table 2. Mean fish abundance of all species combined estimated by trapping and by visual census in the Barbados Marine Reserve (BMR) and in the non-reserve (NR). For the trapping survey the mean fish abundance is the mean number of fish per trap. For the visual census the mean fish abundance is the mean number of fish per census area per census (census area: $240 \mathrm{~m}^{2}$ for trappable size fish and $60 \mathrm{~m}^{2}$ for nontrappable size fish]. n: number of reefs used to calculate the mean. Zones: B: backreef; C-S: combined reef crest-spurs $p$ : probability of 2-tailed $t$-test for separate vanances comparing fish abundance between BMR and NR

\begin{tabular}{|lccccc|}
\hline $\begin{array}{l}\text { Survey } \\
\text { Zone }\end{array}$ & $\begin{array}{c}\text { BMR } \\
\text { Mean (SD) }\end{array}$ & $\mathrm{n}$ & $\begin{array}{c}\text { NR } \\
\text { Mean (SD) }\end{array}$ & $\mathrm{n}$ & \\
\hline $\begin{array}{l}\text { Trapping } \\
\text { Visual census } \\
\text { Trappable }\end{array}$ & $36.1(4.5)$ & 5 & $22.8(7.7)$ & 7 & 0.0035 \\
B & & & & & \\
C-S & $144.6(42.8)$ & 5 & $57.5(31.9)$ & 8 & 0.006 \\
$\begin{array}{l}\text { Non-trappable } \\
\text { B }\end{array}$ & $165.4(25.0)$ & 5 & $100.5(30.3)$ & 8 & 0.004 \\
C-S & $223.7(44.0)$ & 5 & $250.7(48.9)$ & 8 & 0.328 \\
\hline
\end{tabular}
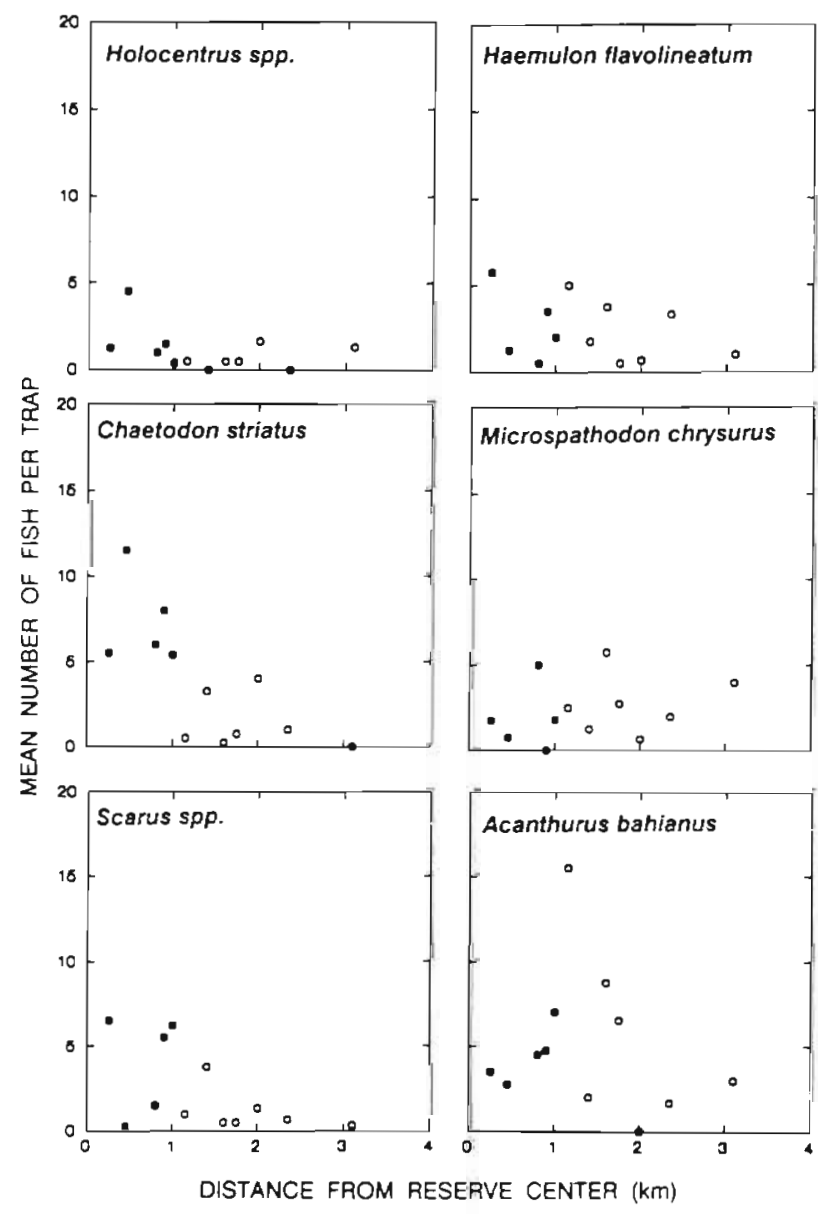

Fig. 4. Mean trap catches per reef of the 6 most common taxa in traps. (•) Reefs in the BMR; (o) reefs in the NR 
a regular decrease with distance from the reserve center. This was true for both the backreef (Fig 5a) and the combined crest-spurs zone (Fig 5b). For the backreef a multiple regression of number of fish per census area on distance from the BMR center and on location of the reef (in the BMR or in the NR) revealed a significant effect of location (partial $p=0.048, \mathrm{df}=1$ ) but not of distance (partial $\mathrm{p}=0.466, \mathrm{df}=10$; overall regression $r^{2}=0.639, p=0.006$; Fig. 5a). For the combined crestspurs zone, there was a highly significant effect of location ( $p=0.002$ ) but only a marginal effect of distance $\left(p=0.089\right.$, overall regression $r^{2}=0.605, p=0.004$; Fig. 5b) The number of trappable fish per census area did not differ between reefs located north and reefs located south of the BMR center either in the backreef $\left(\right.$ mean $_{\text {south }}=85.7, \mathrm{SD}=54.5$, mean $_{\text {noth }}=$ 97.2, $\mathrm{SD}=62.6, t=0.35, \mathrm{df}=10.1, \mathrm{p}=$ 0.733 ) or in the crest-spurs zone (mean $_{\text {south }}$ $=137.4, \mathrm{SD}=48.9$, mean $_{\text {north }}=111.4, \mathrm{SD}=$ 37.0, $t=1.09, \mathrm{df}=10.9, \mathrm{p}=0.30$ ).

For nontrappable fish in the backreef (Fig. 5c) there was no significant trend in abundance in relation to location ( $\mathrm{p}=$ $0.599)$ or distance from the BMR center ( $p=0.402$, overall regression, $r^{2}=0.130$, $p=0.200$ ). For nontrappable fish in the crest-spurs zone (Fig. 5d) there was no effect of location ( $p=0.523$ ) and a marginal positive effect of distance $(p=0.094$, overall regression $\left.r^{2}=0.307, p=0.172\right)$. However, this effect of distance was due to a large aggregation of Haemulon spp. at the most distant reef. Excluding this data point, the effect of distance was not significant.

For the 24 most common taxa, the abundance of trappable fish in the visual censuses was compared between BMR and NR. Abundance was higher in the BMR than in the NR for 16 taxa in the backreef, significantly for 6 , and 19 taxa in the crest-spurs zone, significantly for 7 (Table 4). The proportion of taxa with higher abundance in the BMR was significantly larger than $50 \%$ in the crest-spurs zone $\left(\chi^{2}=8.17, \mathrm{df}=1, \mathrm{p}<0.005\right)$, but not in the backreef $\left(\chi^{2}=2.67\right.$, $\left.d f=1, p=0.10\right)$. In the backreef, the mean number of fish per census area in the NR ranged from 10 to $1971 \%$ of that in the BMR with a median at $86 \%$. In the crest-spurs zone the mean number of fish per census area in the NR ranged from 4 to $328 \%$ of abundance in the BMR with a median at $51.5 \%$ (Table 4).
Regressions of mean number of trappable fish per census area in the crest-spurs zone on distance from the BMR center and location of the reef (BMR or NR) were calculated for the 9 most common taxa, but none showed a significant positive effect of distance and only Scarus vetula showed a significant effect of location (partial $p=0.04$; Fig. 6).

\section{Mean size}

Of 24 taxa for which the comparison was possible, 18 had a larger mean FL in the BMR than in the NR $\left(\chi^{2}=\right.$ $6.0, \mathrm{df}=1, \mathrm{p}<0.025$ ), and this difference was significant for 13 (Table 5). The mean FL in the NR ranged from 75

Table 3. Mean number of fish per trap in the BMR and in the NR for all the taxa sampled by traps. p: one-tailed $t$-test probability for separate variances (for some species $t$-test was calculated on $\log _{10}$ transformed data to approximate normality). $n_{B M R}=5$ reefs and $n_{N R}=7$ reefs. Diff.. relative difference in fish abundance $=(B M R-N R) / B M R$, where $B M R$ and $N R$ are the mean number of fish per trap in the BMR and NR respectively, is indicated only for the common species in traps

\begin{tabular}{|c|c|c|c|c|}
\hline Taxon & $\mathrm{BMR}$ & $N R$ & $\mathrm{p}$ & Diff. \\
\hline Gymnothorax funebris & 0.00 & 0.04 & - & \\
\hline G. moringa & 0.63 & 0.48 & 0.313 & \\
\hline Aulostomus maculatus & 0.05 & 0.07 & 0.406 & \\
\hline Holocentrus spp. & 1.73 & 0.64 & 0.106 & 0.63 \\
\hline Myripristis jacobus & 1.02 & 0.58 & 0.140 & 0.43 \\
\hline Epinephelus fulvus & 0.59 & 0.12 & 0.192 & \\
\hline Rypticus saponaceus & 0.17 & 0.08 & 0.264 & \\
\hline Caranx ruber & 0.20 & 0.74 & 0.146 & \\
\hline C. crysos & 0.15 & 0.00 & - & \\
\hline C. latus & 0.05 & 0.00 & - & \\
\hline Haemulon aurolineatum & 0.70 & 0.55 & 0.308 & 0.22 \\
\hline H. chrysargyreum & 0.55 & 0.51 & 0.460 & 0.07 \\
\hline H. flavolineatum & 2.60 & 2.29 & 0.395 & 0.12 \\
\hline H. sciurus & 0.10 & 0.04 & 0.286 & \\
\hline Lutjanus mahogoni & 0.25 & 0.00 & - & \\
\hline Ocyurus chrysurus & 0.05 & 0.08 & 0.333 & \\
\hline Mulloidichthys martinicus & 0.20 & 0.00 & - & \\
\hline Pseudopeneus maculatus & 0.44 & 0.14 & 0.086 & \\
\hline Kyphosus sectatrix & 0.05 & 0.00 & - & \\
\hline Chaetodon striatus & 7.28 & 1.39 & 0.002 & 0.81 \\
\hline C. capistratus & 2.00 & 0.00 & - & \\
\hline Holocanthus tricolor & 0.00 & 0.12 & - & \\
\hline Pomacanthus paru & 0.25 & 0.39 & 0.250 & \\
\hline Abudefduf saxatilis & 0.40 & 0.04 & 0.208 & \\
\hline Pomacentrus spp. & 0.56 & 0.70 & 0.394 & -0.25 \\
\hline Microspathodon chrysurus & 1.86 & 2.70 & 0.227 & -0.45 \\
\hline Scarus spp. & 3.99 & 1.15 & 0.047 & 0.71 \\
\hline S. vetula & 0.69 & 0.68 & 0.489 & 0.02 \\
\hline Sparisoma spp. & 2.32 & 0.95 & 0.105 & 0.59 \\
\hline S. viride & 0.42 & 0.39 & 0.456 & 0.07 \\
\hline Acanthurus bahianus & 4.50 & 4.96 & 0.415 & -0.1 \\
\hline A. coeruleus & 0.75 & 1.22 & 0.175 & -0.63 \\
\hline Cantherhines pullus & 1.20 & 0.92 & 0.194 & 0.23 \\
\hline Lactophrys spp. & 0.15 & 0.04 & 0.352 & \\
\hline Diodon spp. & 0.24 & 0.10 & 0.303 & \\
\hline
\end{tabular}




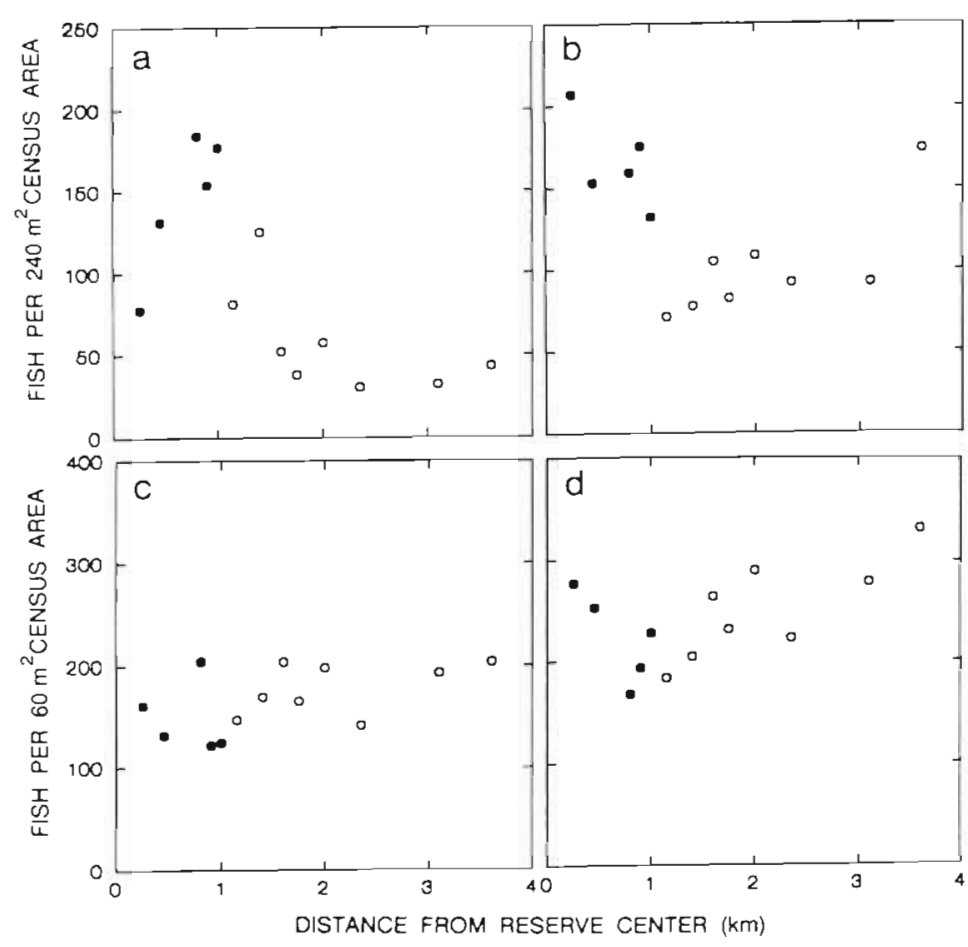

Fig. 5. Mean number of fish of all taxa combined per census area in relation to distance from the BMR center. (a) Trappable size fish in the backreef; (b) trappable size fish in the crest-spurs zone; (c) nontrappable size

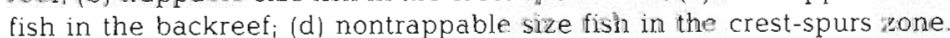
(-) Reefs in the BMR $($ o) reefs in the NR to $117 \%$ of mean FL in the BMR with a median at $96 \%$ (Table 5). The median of the size frequency distributions of the 14 most common taxa was higher in the BMR for 11 taxa, equal in BMR and NR for 1 and higher in the NR for 2 taxa (Rakitin 1994).

\section{Effect of mobility and trappability on fish abundance}

Only taxa that were common in either traps or visual censuses for which both mobility and trappability could be estimated were used in this analysis. For the trapping survey, taxa with more than 0.4 fish per trap in the BMR and more than 0.3 fish per trap in the NR were considered 'common' (Table 3). For the visual censuses, taxa that were present in both the BMR and NR for which at least 30 individuals of trappable size were counted over the entire study area during the 3 censuses were considered common (Tables 1 \& 4). Trappability was estimated and mobility determined for 23 taxa (Table 6).

A total of 7 taxa were classified as S and 16 taxa as $\mathrm{M}$ (Table 6). The snapper Lutjanus mahogoni, the 2 goatfishes Mulloidichthys mar-

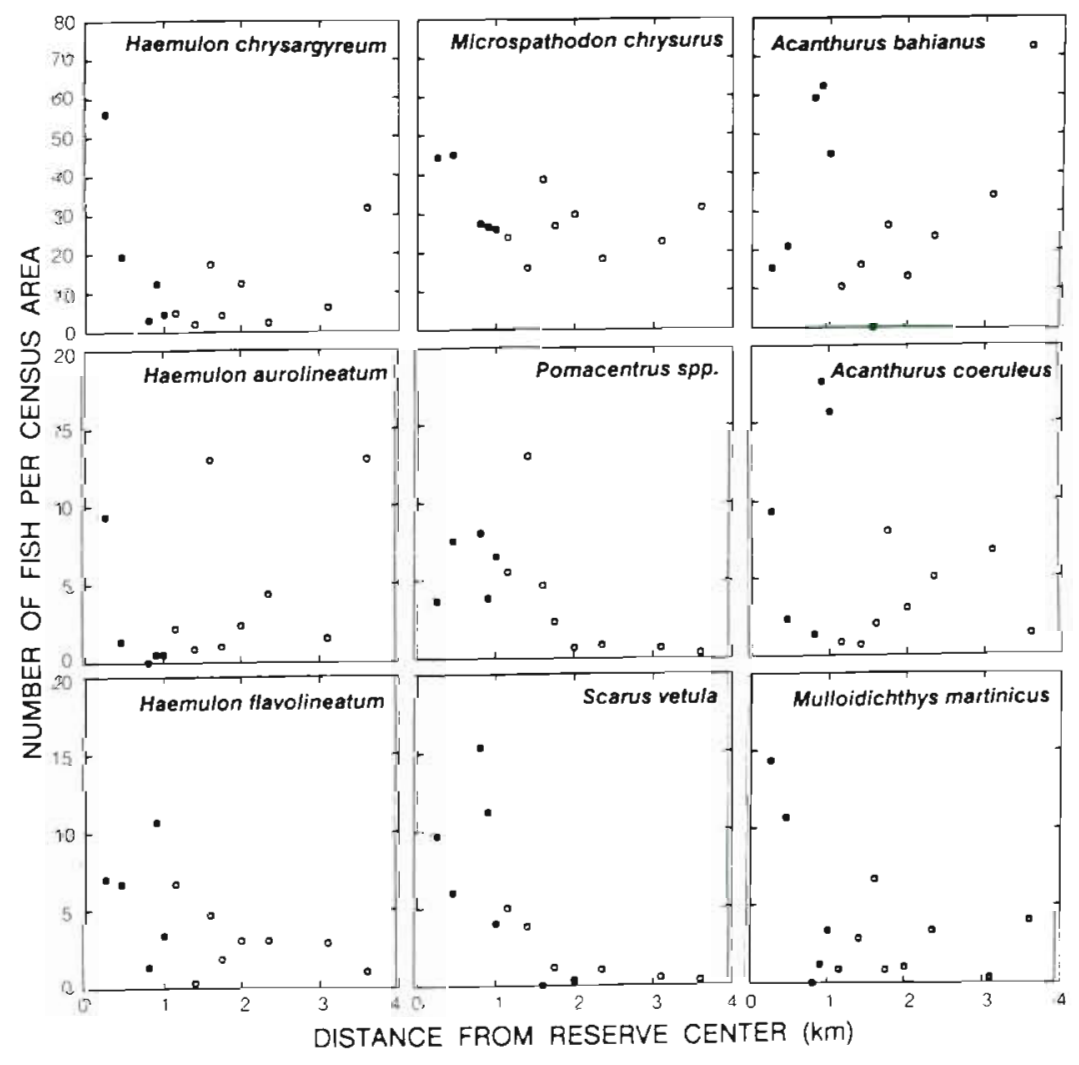

Fig. 6. Mean number of trappable size fish per $240 \mathrm{~m}^{2}$ census area in the crest-spurs zone in relation to distance from the BMR center for 9 common taxa in visual census

(•) Reefs in the BMR; (o) reefs in the NR 
Table 4. Mean number of trappable size fish per census area $\left(240 \mathrm{~m}^{2}\right)$ in the BMR and in the NR for the 24 most common taxa in the visual census, in the backreef and in the crest-spurs zones. $\mathrm{n}_{\mathrm{Bm}}:=5$ reefs and $\mathrm{n}_{\mathrm{NR}}=8$ reefs; $\mathrm{p}=1$-tailed $t$-test probability for separate variances (for some species and reef zones $t$-test was calculated on data $\log _{10}$ transformed to approximate normality). Diff.. relative difference in fish abundance $=(B M R-N R) / B M R$, where BMR and NR are the mean number of fish per census area in the crest-spurs reef zone

\begin{tabular}{|c|c|c|c|c|c|c|c|}
\hline \multirow[t]{2}{*}{ Taxon } & \multicolumn{3}{|c|}{ Backreef } & \multicolumn{3}{|c|}{ Crest-spurs } & \multirow[t]{2}{*}{ Diff } \\
\hline & BMR & NR & $\mathrm{p}$ & $\mathrm{BMR}$ & NR & $p$ & \\
\hline Aulostomus maculatus & 0.27 & 0.21 & 0.421 & 2.00 & 2.20 & 0.320 & -0.1 \\
\hline Myripristis jacobus & 0.00 & 0.08 & & 0.66 & 0.44 & 0.499 & 0.33 \\
\hline Mugil curema & 5.00 & 2.83 & 0.283 & 0.00 & 0.71 & - & \\
\hline Epinephelus fulvus & 0.20 & 0.04 & 0.230 & 1.47 & 1.27 & 0.431 & 0.14 \\
\hline Rypticus saponaceus & 0.00 & 0.04 & & 1.50 & 0.75 & 0.023 & 0.5 \\
\hline Caranx ruber & 0.07 & 1.38 & 0.346 & 1.10 & 3.88 & 0.450 & -2.52 \\
\hline Haemulon aurolineatum & 0.00 & 0.46 & & 2.33 & 4.77 & 0.185 & -1.05 \\
\hline H. chrysargyreum & 0.13 & 0.54 & 0.401 & 19.03 & 10.10 & 0.215 & 0.47 \\
\hline H. flavolineatum & 0.40 & 0.13 & 0.138 & 5.80 & 2.92 & 0.075 & 0.5 \\
\hline Lutjanus mahogonı & 0.33 & 0.00 & & 0.63 & 1.21 & 0.380 & -0.91 \\
\hline Mulloidichthys martinicus & 2.27 & 2.33 & 0.471 & 5.90 & 2.48 & 0.080 & 0.58 \\
\hline Pseudopeneus maculatus & 0.27 & 0.08 & 0.032 & 1.83 & 0.08 & 0.170 & 0.96 \\
\hline Chaetodon striatus & 0.40 & 0.04 & 0.009 & 1.03 & 0.02 & 0.002 & 0.98 \\
\hline Abudefduf saxatilis & 0.00 & 0.00 & & 0.80 & 0.52 & 0.440 & 0.35 \\
\hline Pomacentrus spp. & 0.87 & 1.21 & 0.324 & 5.90 & 3.50 & 0.021 & 0.41 \\
\hline Microspathodon chrysurus & 6.53 & 2.63 & 0.070 & 33.80 & 25.88 & 0.070 & 0.23 \\
\hline Bodianus rufus & 0.13 & 0.21 & 0.337 & 0.67 & 0.17 & 0.024 & 0.75 \\
\hline Scarus spp. & 6.13 & 1.63 & 0.077 & 2.90 & 1.42 & 0.060 & 0.51 \\
\hline S. vetula & 8.71 & 1.29 & 0.004 & 9.23 & 1.52 & 0.001 & 0.84 \\
\hline Sparisoma spp. & 4.53 & 1.21 & 0.007 & 1.63 & 0.61 & 0.120 & 0.63 \\
\hline S. viride & 2.73 & 1.13 & 0.143 & 2.70 & 0.83 & 0.028 & 0.69 \\
\hline Acanthurus bahlanus & 69.6 & 30.7 & 0.004 & 40.57 & 24.63 & 0.150 & 0.39 \\
\hline A. coeruleus & 29.2 & 6.20 & 0.007 & 9.27 & 3.44 & 0.090 & 0.63 \\
\hline Cantherhines pullus & 0.53 & 0.50 & 0.475 & 0.77 & 0.29 & 0.006 & 0.62 \\
\hline
\end{tabular}

tinicus and Pseudopeneus maculatus, and the 2 surgeonfishes Acanthurus bahianus and A. coeruleus were the most common species in traps away from the reefs. $S$ taxa had a slightly but not significantly higher mean relative difference in abundance than $M$ taxa both for traps (mean $_{\mathrm{S}}=0.33, \mathrm{SD}=0.50 ;$ mean $_{\mathrm{M}}=0.12, \mathrm{SD}=0.40 ; t=$ $0.94, \mathrm{df}=13.4, \mathrm{p}=0.363$ ) and for visual censuses (mean $_{\mathrm{S}}$ $=0.46$, mean $_{\mathrm{M}}=0.17$, Mann-Whitney $U$-test statistic $=$ $58, p=0.894)$. Relative difference in abundance for trap catches increased with trappability considering all taxa $\left(r^{2}=0.638, p<0.0005\right), S$ taxa alone $\left(r^{2}=0.946, p=0.001 ;\right.$ Fig, $7 \mathrm{a}$ ) and $\mathrm{M}$ taxa alone $\left(\mathrm{r}^{2}=0.42, \mathrm{p}=0.059\right.$; Fig. $\left.7 \mathrm{~b}\right)$. For the visual census, the relative difference in abundance increased with trappability for $\mathrm{S}\left(\mathrm{r}^{2}=0.785, \mathrm{p}=\right.$ 0.019; Fig. 7c) but not for $M$ taxa ( $p=0.749$; Fig. 7d). S taxa had on average a slightly but not significantly higher trappability than $M$ taxa $\left(\log _{10}\right.$-transformed trappability: mean $_{\mathrm{S}}=-0.07, \mathrm{SD}=0.92$, mean $_{\mathrm{M}}=-0.46, \mathrm{SD}=$ $0.61, t=0.95, \mathrm{df}=7.1, \mathrm{p}=0.372$ ).

\section{Effect of mobility and trappability on fish size}

Only common taxa in traps, for which more precise FL measurements were available, were used here
(Table 5). S taxa did not have a higher mean relative

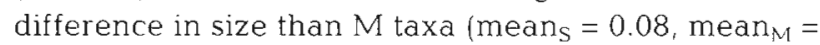
0.04, Mann-Whitney $U$-test $=29, \mathrm{p}=0.81, \mathrm{n}=15$ ) . However, the relative difference in size did increase with trappability for $\mathrm{S}$ taxa $\left(\mathrm{r}^{2}=0.721, \mathrm{p}=0.032\right.$; Fig. 8a) but not for $M$ taxa $\left(r^{2}=0.016, p=0.76\right.$; Fig. $\left.8 b\right)$. The pattern was also significant for the data set as a whole $\left(\mathrm{r}^{2}=0.638, \mathrm{p}<0.0005\right)$. The relative difference in abundance was positively, but not quite significantly, correlated with the relative difference in size for trapping data (Spearman rank correlation $=0.518, p<0.10$ ).

\section{DISCUSSION}

Two questions were asked in this study. The first was whether the BMR protects the fish stocks within its boundaries. The second was whether there is emigration of fish from the reserve.

\section{Protection of fish stocks}

Both trapping and visual census indicated a higher abundance of large trappable size fish in the BMR than 


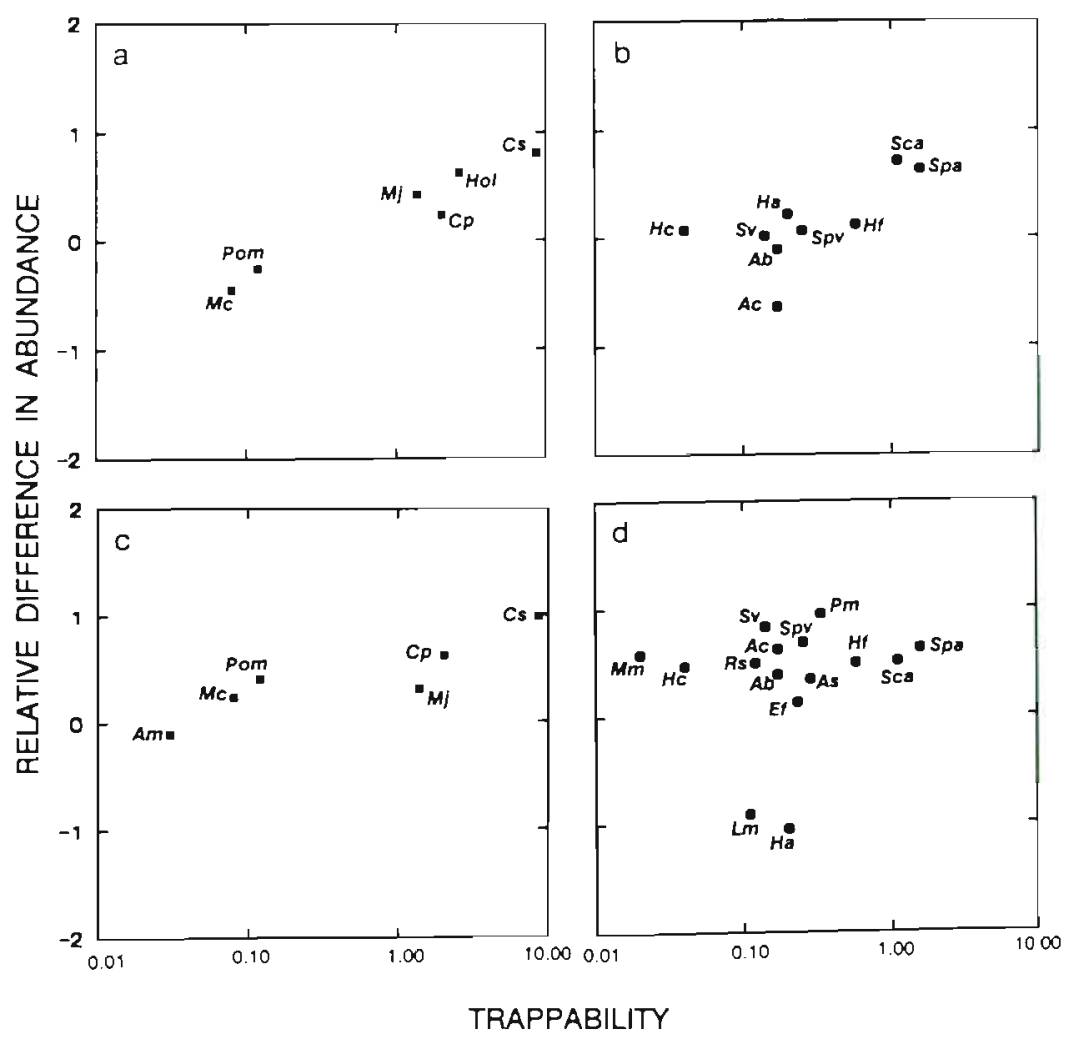

Fig. 7 Relative difference in abundance of trappable size fish between the BMR and the NR in relation to trappability $(a$, b) based on mean catches of common (a) sedentary and (b) mobile taxa in traps; ( $c$, d) based on mean abundances of common (c) sedentary and (d) mobile taxa in visual censuses; Trappability is on a $\log _{10}$ scale Am: Aulostomus maculatus; Hol: Holocentrus spp.; Mj: Myripristis jacobus; Ef: Epinephelus fulvus; Rs: Rypticus saponceus; Ha: Haemulon aurolineatum; $H c: H$ chrysargyreum; Hf: H. flavolineatum; Lm: Lutjanus mahogoni; Mm: Mulloidichthys martinicus; Pm: Pseudopeneus maculatus; Cs: Chaetodon striatus; As: Abudefduf saxatilis; Pom: Pomacentrus spp.; MC: Microspathodon chrysurus; Sca: Scarus spp.; Sv: Scarus vetula; Spa: Sparisoma spp.; Spv: Sparisoma viride; $A$ b: Acanthurus bahianus; Ac: A. coeruleus; Cp: Cantherhines pullus

Table 5. Sizes (FL, cm) of taxa sampled by traps in the BMR and the NR. Range: smallest to largest fish captured; $\mathrm{n}$ : total number of fish captured in 19 trap sets in the BMR and 23 trap sets in the NR; p: probability of Mann-Whitney U-test comparing mean FLs between the BMR and the NR; FL $\mathrm{NLx}_{\text {: }}$ maximum FL attained by the species (Robins et al. 1986); Diff. FL: relative difference in FL = (mean $F L_{B M R}$ - mean $F L_{N R}$ )/FL $L_{\text {mox }}$, only for common taxa

\begin{tabular}{|c|c|c|c|c|c|c|c|c|c|}
\hline Taxon & Mean & $\begin{array}{c}\text { BMR } \\
\text { (Range) }\end{array}$ & n & Mean & $\begin{array}{c}\text { NR } \\
\text { (Range) }\end{array}$ & $\mathrm{n}$ & $\mathrm{p}$ & $F L_{\max }$ & $\begin{array}{l}\text { Diff. } \\
\text { FL }\end{array}$ \\
\hline Holocentrus adscencionis & 18.14 & $(16.0-21.0)$ & 33 & 17.17 & $(14.0-19.0)$ & 17 & 0.073 & 30 & 0.03 \\
\hline Myripristis jacobus & 13.80 & $(11.5-16.0)$ & 22 & 13.34 & $(11.0-16.0\}$ & 13 & 0.27 & 20 & 0.02 \\
\hline Epinephelus fulvus & 20.64 & $(16.5-29.5)$ & 7 & 20.17 & $(17.5-25.0)$ & 3 & 0.82 & & \\
\hline Rypticus saponaceus & 25.50 & $(24.0-28.0)$ & 4 & 20.50 & $(20.0-21.0)$ & 2 & 0.06 & & \\
\hline Caranx ruber & 19.50 & $(18.5-21.5)$ & 4 & 17.13 & $(15.5-23.0)$ & 23 & 0.012 & & \\
\hline Haemulon aurolineatum & 16.58 & $(15.0-21.0)$ & 13 & 16.32 & $(14.5-17.5)$ & 14 & 0.92 & 25 & 0.01 \\
\hline H. chrysargyreum & 16.40 & $(15.0-17.5)$ & 11 & 15.90 & $(15.0-17.0)$ & 11 & 0.055 & 23 & 0.02 \\
\hline H. flavolineatum & 16.50 & $(13.0-19.5)$ & 53 & 15.70 & $(14.0-18.5)$ & 51 & 0.0005 & 30 & 0.03 \\
\hline Pseudopeneus maculatus & 19.86 & $(17.5-22.0)$ & 7 & 20.50 & $(18.0-25.0)$ & 4 & 0.92 & & \\
\hline Chaetodon striatus & 12.20 & $(7.5-14.5)$ & 146 & 9.65 & $(7.5-13.5)$ & 33 & 0.0005 & 15 & 0.17 \\
\hline Pomacanthus paru & 10.25 & $(8.5-11.5)$ & 4 & 12.00 & $(8.0-17.0)$ & 9 & 0.25 & & \\
\hline Abudefduf saxatilis & 11.06 & $(9.5-14.5)$ & 8 & 11.00 & $(11.0-11.0)$ & 2 & 0.287 & & \\
\hline Microspathodon chrysurus & 14.40 & $(9.5-16.0)$ & 31 & 14.12 & $(12.0-16.5)$ & 70 & 0.003 & 20 & 0.014 \\
\hline Pomacentrus spp. & 10.87 & $(10.0-12.5)$ & 12 & 10.81 & $(10.0-11.0)$ & 16 & 0.81 & 15 & 0.004 \\
\hline Scarus spp. & 20.55 & $(16.0-27.5)$ & 81 & 19.55 & $(12.5-25.5)$ & 28 & 0.031 & 33 & 0.03 \\
\hline S. vetula & 26.19 & $(21.0-30.0)$ & 13 & 21.44 & $(16.0-35.0)$ & 17 & 0.012 & 61 & 0.08 \\
\hline Sparisoma spp. & 19.66 & $(15.0-23.0)$ & 35 & 17.71 & $(16.0-20.0)$ & 19 & 0.0005 & 40 & 0.05 \\
\hline Sparisoma chrysopterum & 20.83 & $(16.0-24.5)$ & 3 & 18.50 & $(18.0-19.0)$ & 4 & 0.47 & 40 & \\
\hline S. viride & 23.12 & $(16.0-34.0)$ & 8 & 17.31 & $(15.5-19.0)$ & 8 & 0.007 & 51 & 0.11 \\
\hline Acanthurus bahianus & 14.93 & $(10.5-18.5)$ & 88 & 13.79 & $(10.0-17.0)$ & 157 & 0.0005 & 30 & 0.04 \\
\hline A. coeruleus & 12.69 & $(10.0-17.0)$ & 13 & 12.77 & $(8.5-17.5)$ & 28 & 0.96 & 23 & -0.003 \\
\hline Cantherhines pullus & 17.70 & $(14.5-20.0)$ & 23 & 15.20 & $(11.0-19.0)$ & 24 & 0.0005 & 20 & 0.13 \\
\hline Lactophrys spp. & 11.67 & $(9.5-15.0)$ & 3 & 13.25 & $(10.0-16.5)$ & 2 & 0.56 & & \\
\hline Diodon spp. & 19.00 & $(13.0-22.0)$ & 5 & 19.50 & $(17.0-22.0)$ & 2 & 0.85 & & \\
\hline
\end{tabular}


Fig. 8. Relative difference in fish size between the BMR and the NR in relation to trappability for common taxa in traps: (a) sedentary and (b) mobile taxa. Trappability on $\log _{10}$ scale; species name abbreviations as in Fig. 7

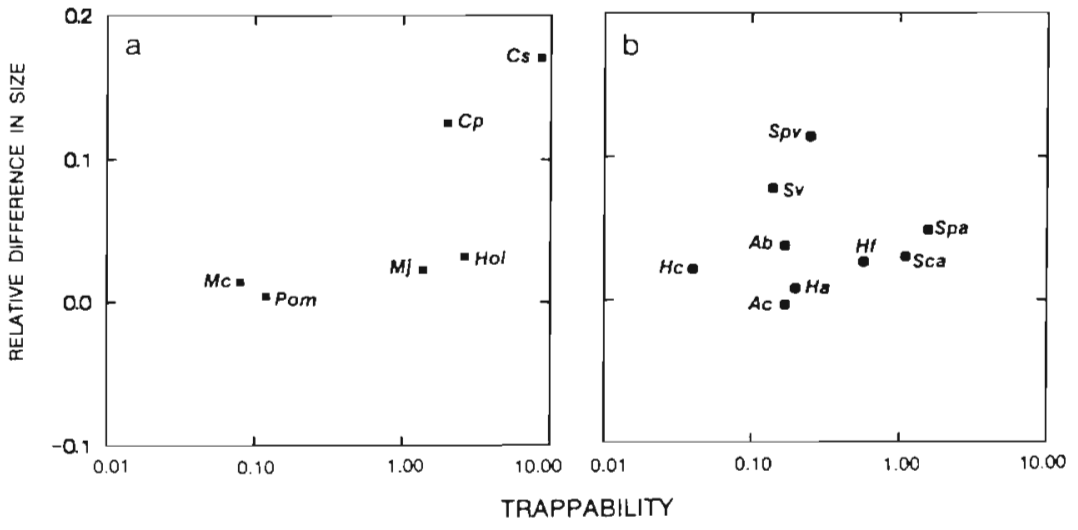

statistically significant for only a few of them. The low number of significant differences was probably due to a high level of variation in fish abundance estimates among reefs and to a small sample size: only 5 reefs in the BMR and 7 (for trapping) or 8 (for visual census) reefs in the NR resulted in a low power for the test. Nevertheless, the chi-squared goodness of fit test indicated that fish taxa have a

Table 6 . List of species for which trappability and mobility were estmated. Mean number of fish per trap in traps set between reefs, at approximately $50 \mathrm{~m}(\mathrm{n}=14$ trap sets). $150 \mathrm{~m}(\mathrm{n}=9)$ and $300 \mathrm{~m}(\mathrm{n}=5)$ from the nearest reef. Source: literature reference for fish mobility: a: Colette \& Talbot (1972); b: Winn et al. (1964); c: Luckhurst \& Luckhurst (1978); d: Colin et al. (1987); e: Randall (1968); f: Randall (1963); g: Moe (1966); h: Starck \& Davls (1966); j: Ogden \& Ehrlich (1977); k: McFarland et al. (1979); l: Gore (1983); m: Stimson (1990); n: Robertson (1988b); o: Bartels (1984); p: Winn \& Bardach (1960); q: Dubin \& Baker (1982); r: Hanley (1984); s: Robertson (1983); t: Robertson (1988a); u: Myrberg and Fishelson (1989); v: Mazeroll \& Montgomery (1995). Mobility: M: mobile; S: sedentary. Trappability $=N_{\mathrm{T}} / N_{\mathrm{v}}$, where $N_{\mathrm{T}}$ is the mean number of fish of species $i$ per trap, averaged over all the reefs, and $N_{\mathrm{v},}$ is the mean number of trappable size fish of species $i$ per census area in the crest-spurs zone, averaged over all reefs

\begin{tabular}{|c|c|c|c|c|c|c|}
\hline \multirow[t]{2}{*}{ Taxon } & \multicolumn{3}{|c|}{ Mean no. of fish $\operatorname{trap}^{-1}$ at } & \multirow[t]{2}{*}{ Source } & \multirow[t]{2}{*}{ Mobility } & \multirow[t]{2}{*}{ Trappability } \\
\hline & $50 \mathrm{~m}$ & $150 \mathrm{~m}$ & $300 \mathrm{~m}$ & & & \\
\hline Aulostomus maculatus & 0 & 0 & 0 & & $\mathrm{~S}$ & 0.03 \\
\hline Holocentrus spp. & 0.08 & 0 & 0 & $a, b, c$ & $\mathrm{~S}$ & 2.63 \\
\hline Myripristis jacobus & 0 & 0 & 0 & $a, b, c$ & $\mathrm{~S}$ & 1.38 \\
\hline Epinephelus fulvus & 0 & 0 & 0 & $d$ & M & 0.23 \\
\hline Rypticus saponaceus & 0.08 & 0.33 & 0.20 & & M & 0.12 \\
\hline Caranx ruber & 1.75 & 0 & 0 & e & M & 0.19 \\
\hline Haemulon aurolineatum & 0 & 0 & 0 & $f, g, h, j, k$ & $\mathrm{M}$ & 0.20 \\
\hline H. chrysargyreum & 0 & 0 & 0 & $f, g, h, j, k$ & M & 0.04 \\
\hline H. flavolineatum & 0 & 0 & 0 & $f, g, h, j, k$ & M & 0.57 \\
\hline Lutjanus mahogoni & 1.08 & 0.67 & 1.20 & & M & 0.11 \\
\hline Mulloidichthys martinicus & 2.63 & 0.72 & 0.60 & & M & 0.02 \\
\hline Pseudopeneus maculatus & 0.75 & 2.17 & 0 & & $M$ & 0.33 \\
\hline Chaetodon striatus & 0 & 0 & 0 & $1, m$ & $\mathrm{~S}$ & 8.65 \\
\hline Abudefduf saxatilis & 0 & 0.11 & 0.20 & $\mathrm{n}$ & M & 0.28 \\
\hline Pomacentrus spp. & 0 & 0 & 0 & 0 & $\mathrm{~S}$ & 0.12 \\
\hline Microspathodon chrysurus & 0 & 0 & 0 & & $\mathrm{~S}$ & 0.08 \\
\hline Scarus spp. & 0 & 0 & 0 & $p, q$ & M & 1.09 \\
\hline S. vetula & 0 & 0 & 0 & p.q & M & 0.14 \\
\hline Sparisoma spp. & 1.46 & 2.97 & 0 & $\mathrm{r}$ & M & 1.55 \\
\hline S. viride & 0 & 0 & 0 & $\mathrm{r}$ & $M$ & 0.25 \\
\hline Acanthurus bahianus & 8.33 & 9.06 & 0.60 & $s, t, u, v$ & $M$ & 0.17 \\
\hline A coeruleus & 8.02 & 6.11 & 3.00 & $s, t, u, v$ & $M$ & 0.17 \\
\hline Cantherhines pullus & 0.17 & 0 & 0.18 & & $\mathrm{~S}$ & 2.01 \\
\hline
\end{tabular}


higher abundance in the BMR more often than they do in the NR.

The mean size of most taxa surveyed by trapping was larger in the BMR than in the $\mathrm{NR}_{4}$ and this difference was significant for 13 out of 24 taxa that were compared (Table 5), but the actual differences were very small. The larger number of significant differences is explained by larger degrees of freedom in the statistical comparison since each individual was considered as a sampling unit.

The abundance and sir: differences imply that the BMR does protect fish stocks, unless the patterns can be explained by factors other than the reduction of fishing mortality. One alternative explanation is that the area now occupied by the BMR had a higher abundance of fish to start with, due to a better habitat quality. Estimations of fish abundance and distribution in the studied area prior to the establishment of the BMR are not available. The Holetown River drains agricultural land into a lagoon which breaks through the beach when a major rainfall occurs, discharging nutrients into the sea close to the center of the BMR (Wells 1988), and possibly causing an increase in productivity. This could attract fishes or increase their growth rates. However, the abundance of small (nontrappable size) fishes was, if anything, higher outside the BMR, making this explanation unlikely. The number of small fish could be controlled by the presence of predators. However, preliminary analyses based on dietary habits showed no trend in the abundance of predators. In general, there was a noticeable lack of large piscivorous fish (groupers and snappers) and the only abundant predators were morays. The greater coastal development in the south than in the north of Barbados has resulted in a gradient of eutrophication, increasing from north to south (Tomascik \& Sander 1987, Allard 1993). However, this gradient was not reflected in the distribution of fish in the BMR and across its boundaries. Some studies have shown that habitat structural complexity is positively correlated with fish abundance (Luckhurst \& Luckhurst 1978, Roberts \& Ormond 1987) and survival (ConnelI \& Jones 1991). But neither reef structural complexity (rugosity) nor reef surface cover composition (percentage of live coral, dead coral, algae or sand) differed statistically between the BMR and the NR (Rakitin 1994). Nevertheless, a higher abundance of large (trappable) fish as well as small (nontrappable) fish was found in the crest and spurs-and-grooves zones where rugosity was high than in the backreef where rugosity was low, which is in agreement with the positive correlation of fish abundance and habitat structural complexity found in other studies. Furthermore, the relative differences in abundance and size of the common taxa in both traps and visual censuses were positively correlated with trappability, i.e. fish taxa suffering a higher fishing pressure show a higher difference in fish abundance between fished and unfished areas. This supports the conclusion that the difference in fish abundance and size between the BMR and the NR is due to the absence of fishing pressure in the BMR rather than to a difference in habitat quality.

Several previous studies have obtained results comparable to those found in this study. Bell (1983) found that the densities of species vulnerable to the fishery were 1.2 times higher on a reef inside a reserve in the Mediterranean Sea (France) than on a similar reef outside of the reserve, at 2 different depths. Bell (1983) indicated that 11 out of 35 species $(31 \%)$ recorded in that study were significantly more abundant in the reserve areas, and 10 of these were fished species. Alcala (1988) found an overall density of fishes 1.4 times higher in the Apo Island Reserve (The Philippines) than in similar non-reserve areas. Polunin \& Roberts (1993) studied 2 marine reserves in the Caribbean and showed that the overall fish biomass was 1.9 and 2 times greater in reserve than in nonreserve areas. They found that $59 \%$ of the fished species in the Saba Marine Park (Netherlands Antilles) and $45 \%$ in the Hol Chan Marine Reserve (Belize) had a greater abundance, biomass or size than in similar non-reserve areas. These ratios compare to those obtained in the present study: mean trap catches were 1.6 times and visual census fish counts 1.7 times (backreef) and 2.5 times (crest-spurs zone) higher in the BMR than in the NR, while $69 \%$ of the common species in traps, $58 \%$ in the backreef visual censuses and $79 \%$ in the crest-spurs visual censuses were more abundant in the BMR than in the NR.

It has been argued that fishing affects large piscivorous species more than other groups of fish, because the former are usually targets of fishermen and more easily retained by the gear (Munro \& Williams 1985, Russ 1991.). This notion is supported by the results of several studies (e.g. Koslow et al. 1988, Buxton \& Smale 1989, Russ \& Alcala 1989). On the same basis, Russ (1985) suggested that abundance of piscivorous fish could be an indicator of fishing pressure. However, larger piscivorous fishes were practically absent on the fringing reefs of the west coast of Barbados. Very few large jacks and groupers were seen in the BMR. This could well be an indication of a general overfishing in Barbados together with a relatively weak enforcement of the reserve regulations (a Coast Guard boat patrols the shore once a day; A.R. pers. obs.). In the present study chaetodontids and scarids showed a consistent significant difference in abundance and size between BMR and NR (Tables 3 \& 4). Ferry \& Kohler (1987) compared fish abundances and sizes in 2 areas of shallow water fringing reefs in Haiti that differed in fishing 
intensity and found that scarids and chaetodontids were significantly larger in the less fished area. This coincidence in results is probably explained by the similarity of the study areas: both were shallow water fringing reefs subjected to coastal trap fishing. Scarids and chaetodontids are both very vulnerable to trap fishing and, although chaetodontids are not marketable fish, fishermen usually keep all the catch. The evidence strongly suggests that fishing negatively affects the abundance and size of reef fishes and that marine reserves are effective in protecting fish stocks within their boundaries. However, the magnitude of the effect of reserves on fish abundance and size varies among different areas and among individual taxa. This is likely a consequence of several factors, i.e. the habitat where reserves are located and the species composition of the fish community, the duration and level of enforcement of the reserve protective management and, most importantly, the levels of fishing pressure outside of the reserve and the type of local fishing gear.

\section{Emigration of fish from the reserve}

Emigration of fishes from reserves has been proposed as a potential beneficial effect of reserves for fisheries (Roberts \& Polunin 1991, 1993) and has also been suggested as a possible explanation for the lack of significant differences in fish abundance between reserve and non-reserve areas (Polunin \& Roberts 1993). In spite of that, it has never been tested directly. This is probably because direct measurements of fish movements by radiotracking or tagging are very expensive and time consuming, restricting the number of species that can be studied at one time. In the present study, an alternative indirect measure of emigration was used based on patterns of distribution across the reserve boundaries.

The evidence we found for emigration of fish from the BMR was limited and inconsistent. The gradual decrease in trap catches with distance from the center of the reserve supported the emigration hypothesis. However, in the visual census the gradient of trappable fish abundance was not evident in the backreef and only marginally significant in the crest-spurs zone. Neither trap nor visual census estimates showed a gradual decrease in fish abundance for individual taxa. Moreover, sedentary taxa did not show a significantly higher relative difference in size and abundance than mobile taxa as would be expected if at least the mobile fish were emigrating, though all the trends were in the predicted direction. The fact that sedentary taxa showed a much stronger increase in relative difference in abundance than mobile taxa, estimated by both trapping and visual census as well as in size with trap- pability, does provide some support for the emigration hypothesis. While the evidence is not enough to prove that emigration from the BMR is frequent, neither does it allow the rejection of that possibility. Probably, a more refined mobility categorization based on siteand species-specific studies of movement habits of fishes is needed.

The patchy nature of the environment studied here (the fringing reefs are separated by sometimes extensive areas of sand and gravel) might act as a barrier for the movement of fish to assess habitats. Habitat discontinuities might not be perceived in the same manner by all animals (Wiens et al. 1985). Mobile animals should be able to cross some habitat discontinuities more easily than sedentary animals; the sand and rubble areas separating reefs may represent an impassable barrier for strictly reef dwelling sedentary fish but not for mobile fish. However, even some mobile fish may not readily take the risk of travelling over long distances of sand. Increased travel cost between habitat patches may prevent animals from moving and visiting habitats, leading to distributions different from that predicted by Ideal Free Distribution (Bernstein et al. 1991).

Nevertheless, many of the fish taxa considered mobile in this study were able to travel over sand for distances long enough to take them from one reef to another. Most of the evidence of Caribbean coral reef fish mobility concerned precise periodic migrations, such as the diel feeding migrations performed by grunts (Starck \& Davis 1966, Ogden \& Ehrlich 1977 , Ogden \& Quinn 1984) and parrotfishes (Winn \& Bardach 1960, Dubin \& Baker 1982) or the spawning migrations of surgeonfishes (Myrberg \& Fishelson 1989, Mazeroll \& Montgomery 1995) characterized by a strong homing behaviour. There is very little evidence of exploratory movements leading to relocation of fishes (Robertson 1988a, b). Some of the taxa considered mobile, therefore, might actually be unwilling to relocate. Additionally, habitat use patterns of a particular species may vary in different habitats, e.g. some fish may move over sand if there is seagrass but bare sand might inhibit them. In other coral reef environments where some of the studies which provided data for the mobility classification were carried out, reefs are surrounded by seagrass and sand. This is not the case on the west coast of Barbados where the fringing reefs are separated by areas of only sand and rubble, with occasional small patch reefs. Therefore, the mobility classification used here might be inadequate. An example of such possible misclassification could be grunts, which were considered mobile based on ample evidence found in the literature, but were absent from traps set away from reefs even though they were common in traps on reefs. 


\section{Conclusion}

This study indicated that the BMR protects the fish community. There was insufficient evidence for emigration of fish from the reserve to the fishery, but neither could it be firmly ruled out. Trappability seemed to be better than mobility for predicting the effect of the reserve on the abundance and size of fishes. Both mobility and trappability depend on complex behavioral traits that seem to be important in the functioning of marine reserves. Further study in different locations is needed to assess the importance of mobility and vulnerability to the fishing gear for the effect of reserves on fish abundance and size distributions.

Acknowledgements. This paper is based on a MSc thesis submitted by A.R. at McGill University. We thank the members of A.R.'s supervisory committee, Wayne Hunte and James Grant, for their ideas and encouragement. We appreciate very much the help received from Hazel Oxenford Christopher Parker, Pietr De Boes and from all the staff of Bellairs Research Institute during the field data collection. We also thank Ross Robertson, Robert Warner and Callum Roberts for providing useful information on the mobility of fishes. James Grant, Joseph Rasmussen, Callum Roberts and an anonymous reviewer provided constructive comments on the manuscript. A.R. received financial support from the Canada International McGill/CIDA Fellowship. Research expenses were supported by an NSERC research grant to D.L.K.

\section{LITERATURE CITED}

Alcala AC (1988) Effects of a marine reserve on coral fish abundances and yields of Philippine coral reefs. Ambio 17: $194-199$

Allard P (1993) Changes in coral community structure in Barbados: effects of eutrophication and reduced grazing pressure. MSc thesis, McGill University, Montreal

Bartels PJ (1984) Extra-territorial movements of a perennially territorial damselfish, Eupomacentrus dorsopunicans Poey. Behaviour 91:312-321

Bell JD (1983) Effects of depth and manne reserve fishing restrictions on the structure of a rocky reef fish assemblage in the North-western Mediterranean Sea. J appl Ecol 20:357-369

Bernstein C, Kacelnik A, Krebs JR (1991) Individual decisions and the distribution of predators in a patchy environment. II. The influence of travel costs and structure of the environment. J Anim Ecol 60:205-225

Bohnsack JA (1982) Effects of piscivorous predator removal on coral reef fish community structure. In: Gaillet GM, Simenstad CA (eds) Gutshop '81: fish food habits studies. Washington Seagrant Publication, University of Washington, Seattle, p 258-267

Bohnsack JA, Harper DE, McClellan DB (1992) Marine reserves for reef fishes: lessons from partially protected areas in the Florida Keys, USA (abstract). Proc 7 th Int Coral Reef Symp, Guam 2:993

Buxton CD. Smale MJ (1989) Abundance and distribution patterns of three temperate marine reef fish (Teleostei: Sparidae) in exploited and unexploited areas off the southern Cape Coast. J appl Ecol 26:441-451
Colin PL, Shapiro DY, Weiler D (1987) Aspects of the reproduction of two groupers, Epinephelus guttatus and $E$. striatus in the West Indies. Bull mar Sci 40:220-230

Collette BB, Talbot FH (1972) Activity patterns of coral reef fishes with emphasis on nocturnal-diurnal changeover. In: Collette BB, Earle SA (eds) Results of the Tektite program: ecology of coral reef fishes. Natural History Museum of Los Angeles County. Los Angeles, p 98-124

Connell SD, Jones GP (1991) The influence of habitat complexity on postrecruitment processes in a temperate reef fish population. J exp mar Biol Ecol 151:271-294

DeMartini EE (1993) Modelling the potential of fishery reserves for managing Pacific coral reef fishes. Fish Bull US 91:414-427

Dubin RE, Baker JD (1982) Two types of cover-seeking behaviour at sunset by the princess parrotfish, Scarus taeniopterus, at Barbados, West Indies. Bull mar Sci 32: $572-583$

Ferry RE, Kohler CC (1987) Effects of trap fishing on fish populations inhabiting a fringing coral reef. N Am J Fish Manage 7:580-588

Fretwell SD, Lucas HL (1970) On territorial behaviour and other factors influencing habitat distribution in birds. I Theoretical development. Acta Biotheor 19:16-36

Gore MA (1983) The effect of a flexible spacing system on the social organization of a coral reef fish, Chaetodon capistratus. Behaviour 85:118-145

Hanley F (1984) Time-budgeting and foraging strategy of the stoplight parrotfish Sparisoma viride Bonnaterre, in Jamaıca. J exp mar Biol Ecol 83:159-177

Hobson ES (1973) Diel feeding migrations in tropical reef fishes. Helgoländer wiss Meeresunters 24:361-370

Koslow JA, Hanley F, Wicklund R (1988) Effect of fishing on reef fish communities at Pedro Bank and Port Royal Cay, Jamaica. Mar Ecol Prog Ser 43:201-212

Lewis JB (1960) The coral reefs and coral communities of Barbados WI. Can J Zool 38:1133-1145

Luckhurst BE, Luckhurst K (1978) Analysis of the influence of substrate variables on coral reef fish communities. Mar Biol 49:317-323

Mazeroll AI, Montgomery WL (1995) Structure and organization of local migrations in brown surgeonfish (Acanthurus nigrofuscus). Ethology 99:89-106

McFarland WN, Ogden JC, Lythgoe JN (1979) The influence of light on the twilight migrations of grunts. Environ Biol Fish 4:9-22

Miller RJ, Hunte W (1987) Effective area fished by Antillean fish traps. Bull mar Sci 40:484-493

Moe MA (1966) Tagging fishes in Florida offshore waters. Tech Ser Fla St Bd Conserv 49:1-40

Munro JL (1974) The mode of operation of Antillean fish traps and the relationships between ingress, escapement and soak. J Cons int Explor Mer 35:337-350

Munro JL (1983) Caribbean coral reef fishery resources, 2nd edn. International Center for Living Aqquatic Resources Management, Manila

Munro JL, Williams DM (1985) Assessment and management of coral reef fisheries: biological environmental and socioeconomic aspects. Proc 5th int Coral Reefs Congr 4: 545-581

Myrberg AA JI, Fishelson L (1989) Ecology of three reefdwelling surgeonfishes (Acanthuridae) in the Red Sea with particular reference to feeding. J exp mar Biol Ecol 132:179-207

Nelson JS (1994) Fishes of the world, 2nd edn. John Wiley and Sons, New York

Ogden JC. Ehrlich PR (1977) The behaviour of heterotypic 
resting schools of juvenile grunts (Pomadasydae). Mar Biol 42:273-280

Ogden JC, Quinn TP (1984) Migration in coral reef fishes: ecological significance and orientation mechanisms. In: McLeave JD, Arnold GP, Dodson JJ, Neill WH (eds) Mechanisms of migration in fishes. Plenum, New York, p 293-308

Pollard DA (1977) The concept of marine conservation and recreation reserves, with special reference to recent developments in Australia. Collected abstracts and papers of the International Conference on marine parks and reserves, Tokyo, Japan. Bull mar Park Res Stns (Japan) $1: 180-193$

Polunin NVC, Roberts CM (1993) Greater biomass and value of target coral reef fishes in two small Caribbean marine reserves. Mar Ecol Prog Ser 100:167-176

Power ME (1984) Habitat quality and the distribution of algae-grazing catfish in a Panamanian stream. J Anım Ecol 55:357-374

Rakitin A (1994) The effect of a marine reserve on the abundance and size of coral reef fishes in Barbados, West Indies. MSc thesıs, McGill University, Montreal

Randall JE (1963) An analysis of the populations of artificial and natural reefs in the Virgin Islands. Caribb J Sci 3: $31-47$

Randall JE (1968) Caribbean reef fishes. TFH Publications, Inc, New York

Roberts CM. Ormond RFG (1987) Habitat complexity and coral reef fish diversity and abundance on Red Sea fring. ing reefs. Mar Ecol Prog Ser 41:1-8

Roberts CM, Polunin NVC 11991 ) Are marine reserves effective in management of reef fisheries? Rev Fish Biol Fish 1. $65-91$

Roberts CM, Polunin NVC (1993) Marine reserves: simple solutions to managing complex fisheries? Ambio 22: $363-368$

Robertson DR (1983) On the spawning behaviour and spawning cycles of eight surgeonfishes (Acanthuridae) from the Indo Pacific. Environ Biol Fish 9:193-223

Robertson DR (1988a) Abundances of surgeonfishes on patchreefs in Caribbean Panama: due to settlement, or post settlement events? Mar Biol 97:495-501

Robertson DR (1988b) Settlement and population dynamics of Abudefduf saxatilis on patch reefs in Caribbean Panama. Proc 6th int Symp Coral Reefs 2:839-844

Robins CR, Ray GC, Douglass J (1986) The Peterson field

This article was submitted to the editor guide series. A field guide to Atlantic coast fishes of North America. Houghton Mifflun Company, Boston

Russ GR (1985) Effects of protective management on coral reef fishes in the central Philippines. Proc 5th int Coral Reef Congr 4:219-224

Russ GR (1991) Coral reef fisheries: effects and yields. In: Sale PF (ed) The ecology of fishes on coral reefs. Academic Press, Inc, San Diego, p 754

Russ GR, Alcula AC (1989) Effects of intense fishing pressure on an assemblage of coral reef fishes. Mar Ecol Prog Ser 56:13-27

Sale PF (1980) The ecology of fishes on coral reeis. Oceanogr mar Biol A Rev 18:367-421

St. Hill YL (1987) The protected areas of Barbados, Report no. 2. Management plan for the Barbados Marme Reserve. Environmental Unit, Ministry of Employment, Labour and Community Development, Bridgetown, Barbados

Starck WA, Davis WP (1966) Night habits of fishes of Alligator Reef, Florida. Ichthyol A.quarium J 38:313-356

Stearn CW, Scoffin TP, Martindale W (1977) Calcium carbonate budget of a fringing reef on the west coast of Barbados. Part 1 - Zonation and productivity. Bull mar Sci 27:479-510

Stimson JS (1990) Density dependent recruitment in the reef fish Chaetodon miliaris. Environ Biol Fish 29:1-14

Tomascik T. Sander, F (1987) Effects of eutrophication on reef-building corals Ir. Structure of scleractinian coral communities on fringing reefs, Barbados, West Indies. Mar Biol 94:53-75

Upton HF (1992) Biodiversity and conservation of the marine environment. Fisheries 17:20-25

Wallis OL (1971) Establishing underwater parks worldwide. Trans N Am Wildl Nat Resour Conf 36:97-115

Wells SM (ed) (1988) Coral reefs of the world, Vol 1: Atlantic and Eastern Pacific. International Union for Conservation of Nature and Natural Resources, Cambridge, UK

Wiens JA, Crawford CS, Gosz JR (1985) Boundary dynamics: a conceptual framework for studying landscape ecosystems. Oikos 45:421-427

Wilkinson L. (1990) SYSTAT: the system for statistics. SYSTAT, lnc, Evanston, IL

Winn HE, Bardach JE (1960) Some aspects of the comparative biology of parrotfishes at Bermuda. Zoologica 45:29-34

Winn HE, Salomon M, Roberts N (1964) Sun-compass orientation by parrotfishes. Z Tierpsychol 21:798-812

Zar JH (1984) Biostatistical analysis, 2nd edn. Prentice Hall, Inc, Englewood Cliffs, NJ

Manuscript first received: July 11, 1994

Revised version accepted: June 6, 1995 